\title{
The Development of Auditing in the Public Sector in Albania and Responsible Institutions
}

\author{
Nensi Xhani \\ PhD Student, University of Craiova, \\ Faculty of Economics and Business Administration, Romania \\ Marioara Avram \\ Professor PhD, University of Craiova, \\ Faculty of Economics and Business Administration, Romania \\ Maria-Andreia Iliescu (Ristea) \\ PhD Student, University of Craiova, \\ Faculty of Economics and Business Administration, Romania
}

\begin{abstract}
Auditing in the public sector has evolved over the years to meet the needs of a business environment that is constantly changing. In an effort to help organizations achieve an accurate assessment of risk and business development, internal audit plays a particularly important role. Although internal audit has existed since the beginning of human civilization, in Albania it developed much later. The economic and financial development of Albania over the last decades, in the context of economic globalization, has had a significant impact on auditing institutions, that have to do their best to measure the efficiency of public fund usage. This paper aims to analyze the historical development of auditing in the public sector, and measure by quantification the performance of the institutions that have been responsible for organizing auditing in the public sector in Albania, as well as identifying the national and international policies that have brought about the introduction and evolution of the audit concept. Recognizing the genesis of the public sector audit activity and the progress of the responsible institutions, we can understand the current situation and the needs for change that would increase the efficiency of work in those institutions.
\end{abstract}

Keywords: internal audit, external audit, internal control, evolution

\section{Introduction and Context of the Study}

Over the last 29 years, Albania has experienced economic, political and social progress in the national and international impact. Eventhough the audit has existed at an early age, the standard practice of auditing has been developed only in the last two decades. The need to prevent abuse, mismanagement and corruption of public funds has brought the demand for internal and external auditing. According to Brown (1905) the origin of 


\section{Journal of International Cooperation and Development \\ www.richtmann.org/journal \\ Vol 3, No 1, May 2020}

auditing goes back to times scarcely less remote than that of accounting. Whenever the advance of civilization brought about the necessity of one man being entrusted to some extent with the property of another, the advisability of some kind of check upon the fidelity of the former would become apparent. In the context of profound economic financial changes which happen on both the national and the global level, both the need and the opportunity continuous and more emphasized involvement of the information provided by the annual financial situations in the management process is obvious, in the conditions of increasing their credibility and relevance in the users' perception (Avram $M, 2013)$.

The first records of the audit history can be traced back to 4000 B.C. in the Near East. Other traces of need for audit activity can be found in Babylonia, Greece, the Roman Empire, the City States of Italy (Venice, Genoa, Firenze) etc. The audit process is a well-established institution of a developed society. It is a process on which the members of society call and rely (Flint, 1988). How to cultivate, and keep informed the investing public and the professional investment advisers who influence their opinions, has become a primary concern of management in the increasingly competitive financial markets (Mautz \& Sharaf, 1961). Financial communication has become a strategic concern, managed at the level of corporate governance that ensures the transparency of financial information and contributes to proving the credibility of an entity among stakeholders (Avram C. D, 2017)

The analysis of the historical phases regarding the auditing process can be divided into two eras: the era of prehistory and the era of modern development of the audit. The boundary between them can be linked to the beginning of the road towards the concept of independence for the audit structures. Audit, as a process and a profession, was also considered very primeval so much that writing was invented precisely to satisfy the need for audits (Çela, 2017). Auditing is an academic discipline and professional workmanship, even while is born of the accounting framework, as a consequence of social and economic developments (Cibaku, 2010). Throughout surveying the accounting history literature, Matthews (2006) demonstrated the lack of interest in audit history where has been very limited primary research into the history of the audit on either side of the Atlantic, and none of historians pays attention to what auditors actually did. In the government sector, there has been a demand for auditing for a considerable period, but an independent audit function has tended to be imposed for agency or management control reasons (Hay and Cordery, 2016).

The purpose of this paper presents the development and the importance of the public sector audit activity in supporting good governance, considering the fact that it is based on both internal audit and external audit. Public sector audit contributes to the use of effective, efficient, accountable and transparent public funds to achieve the objectives of public sector entities and has become a cornerstone of strong and sustainable governance. 


\section{Journal of International Cooperation and Development \\ www.richtmann.org/journal \\ Vol 3, No 1, May 2020}

\section{Methodology}

This research is exploratory, qualitative and essentially reviews existing literature on the history and progression of the auditing approach in Albania with the single aim of explaining the reason for the usefulness of the audit process in the current period. The objectives of the paper follow the evolution of the audit, focusing on the public sector and the responsible institutions for this activity. Therefore, we began by analyzing the significant moments of the audit's development in Albania, specifying the culminating events and evolutions so far. During the research, we have also focused on statistics and we have conducted a quantitative analysis of the performance of ALSAI in terms of economic damage and usefulness during the last decades, based on the ALSAI Performance Reports over the period 2012-2018.

\section{The Birth and Development of Audit Institutions in Albania (1912-2019)}

From the research of the history of the establishment of the Albanian high-level financial control service, we notice note that it has his beginnings with the period of the Declaration of National Independence in 1912, which brought a new way of organizing both state and economic activities. The organization and functioning of this structure dates back to full 13 years after the birth of the Albanian state, in 1925, starting with the Congress of Lushnja, the Republic, the Constitutional Monarchy, during the totalitarian Communist regime and continues today, adapting to it historical, functional, organizational changes, appointments, competencies, roles, dependencies and the object of activity. Based on the History of ALSAI (Naska et al., 2012; Angjeli 2014) since its establishment up to the present day, the ways of organizing and conducting the audit activity are as follows:

1. At the time of the Provisional Government of Vlora, headed by Ismail Qemali, was elected a Council of the Elders, as a body of advice and control over the government, which never functioned as an institution. In the "Municipal Canon of Civil Administration" (Art.24/2) it was determined that the Director of Finance had the right to control the office accounts. With the approval of the Organic Statute of Albania, based on the decisions of the Conference of Ambassadors of the Great Powers in London (The London Conference, July 29, 1913), the administration and finance control of Albania that had the Provisional Government of Vlora and the local authorities passed the International Commission of Control, which would be represented by Prince Vidi with a term of 10 years.

2. With the formation of the Democratic Government headed by Fan Noli (June 16, 1924), according to the Decree-Law of the High Council of State, August 29, 1924, was established as a temporary structure the Committee for the Control 
of Financial Accounts of the Center at the Ministry of Finance, which would check all the accounts up to that time.

3. At the time of the Government of Ahmet Zogu (1925-1939) we can say that for the first time in the Albanian state-building history, the control institutions were raised and organized at the highest legal-constitutional level. During the Congress of Lushnja (28-31 January 1920), appeared the legal and constitutional control reports of the Parliament on the Government. The genesis origins of the controls of this regime are seen from the end of 1920 and the beginning of 1921 with the establishment of a Control Commission. Under the Statute of the Albanian State 1922, the main control tool were the Investigative Commissions, while for a continuous control over the finances was founded the Financial Control Council, independent, with a chairman and two members, based on Articles 75-79 of the Statute and the Decree - Law of 20 May 1925. With the approval of the Law "On the Organization and Functioning of the Control Council" on April 23, 1929, a new division of control sectors was introduced, a further specialization of the control-revision, as well as the Prosecutor became part of the Control Council, which it does not appear in the Constitution of 1938. In addition to the Control Council, there was also the Royal Court Inspectorate (Art. 88) which inspected all state and pertinent administration actions. Although independent, the Control Council seem not only dubbed in his work, but his activity passed once in three months for approval to the King

4. The Fundamental Statute of the Kingdom of Albania (June 4, 1939) dissolved the existence of the Control Council and established the State Control Institution as part of the Italian Kingdom by Decree no. 44, dated 13 July 1939 on "The Function of the Control Council".

5. During the 45-year period of communist regime in Albania (1945-1990) several decrees and laws have been issued, by transforming or reforming the control system many times. After the liberation of the country by the Nazi - fascist invaders, the Anti - Fascist National Liberation Council adopted Law No. 97, 19 July 1945, "On the Organization and Functioning of the Control Council", which had a multiple dependency and it was not independent. In the framework of the reorganization of the control bodies, the Law no. 277, dated 14 August 1946, "On the General State Control" was approved, which again had a lack of independence. This law was revoked with the issuance of Law no. 784, dated 20.01.1950 "On the State Control Committee". The abovementioned law has abrogated by the Decree no. 1480, dated 12 June 1952, where the Ministry of Control has been established, as the highest control body of the state exercising control. By Decree no. 2878, dated 6.4.1959, the name of the Minister of Control changed to the State Control Commission. The State Control Commission was abolished by Law no. 4122, dated 17.03.1966, "For the 
unification and abolition of several ministries" taking the form of State Inspection until 1982, as a constituent part of the Council of Ministers apparatus. In order to increase the role of influence of the control bodies over management of the common property, by the Decision of the Council of Ministers no. 301, dated 22.10.1982, "On the duties and rights of the State Inspections", it was reorganized as an organ within the Council of Ministers' apparatus. The State Inspection, with a political platform dictated by the Labor Party of Albania (the ex communist party), exercised custom control on behalf of the Government, ministries, executive committees, enterprises, institutions, units, united units, military departments and agricultural cooperatives. According to Law no. 7108, dated 21.02.1987, was established the State Control Commission, which acted as a collegiate and decision-making body at ministerial level. The State Control Commission have checked the implementation of the Council of Ministers' decisions and measures taken to improve the administration and maintenance of socialist property, as well as oversee and take measures to strengthen internal and specialized control by other state and economic bodies. This body has been a formal member of INTOSAI since 1984.

6. With the establishment of pluralism in Albania, a restructuring of the control institution were needed in line with the requirements of international standards in the field of public administration and control. According to Decision no. 162, dated 07.05.1992 of the Council of Ministers, the State Control Commission took over the attributes of the control - revision, which it exercised until 2000. After the approval of Law no. 7596, dated 31.8.1992 "On the the State Control Service ", laid the foundations of the highest economic and financial control body, which was different in form and content from the functions and organizational previous structures. In exercising his powers, he was independent and he submitted only to the Constitution and the Law.

7. With the entry into force of Law no. 8270, dated 23.12.1997, the name of the State Control Service was changed "The Supreme State Audit" and was ensured the full institutional, organizational and functional independence. The Law No. 8599, dated 01.06 .2000 consisted in determining the authority and functioning of the Supreme State Audit as the highest institution of financial and economic control in the Republic of Albania, the mandate and the powers of the Chairman, the way of reporting etc.

8. To reflect changes which have occurred in practice both internally and externally of Albania, compliance with international standards and the strengthening of the legal framework was adopted the Law No. 154/2014 "Organization and Functioning of the State Supreme Audit Institution", which is still in force today, passing from a control-revision institution of the financial statements to an Audit Institution. This law realizes the profiling of ALSAI as a modern institution, 


\section{Journal of International Cooperation and Development}

www.richtmann.org/journal

Vol 3, No 1, May 2020

includes two other types of audit (performance audit and IT audit), improves the relationship between obtaining information from audited entities, expands the competencies of ALSAI, and strengthens the institutional, economic and organizational independence.

\section{A Brief History of the Albanian Audit Process Nowadays}

The Public Finance Management Strategy 2014-2020 in Albania, which is organized in six pillars, defined as the 5th Pillar, Internal Audit, with objective well-functioning and efficient IA function in the public sector, whereas Pillar 6 - Effective external oversight of the public finances with objective strengthening the external oversight function by bringing it in line with INTOSAI standards.

As one of the three pillars of Public Internal Financial Control (PIFC), internal audit has already established the basic legal framework, which has been updated over the years to ensure full compliance with best practices in the field of auditing and International Standards for the Professional Practice of Internal Auditing. In order to strengthen the principle of internal audit independence, several steps were taken to: the establishment of audit committees, determining the responsibilities of the heads of public bodies, managers and internal auditors, setting specific employment criteria for auditors, as well as strengthening the certification process and continuous professional training of internal auditors in the public sector, and thus prepared the conditions for adoption of the Law No.114/2015 "On Internal Audit in Public Sector". To accomplish the objectives of the law, the Minister of Finance is supported by the Public Internal Financial Control Board and the responsible structure for harmonizing the internal auditing of the Ministry of Finance. The definition of internal audit in the public sector has changed over time as shown in Table 1 :

Table 1: Definition of internal audit in Albania

\begin{tabular}{|l|l|l|}
\hline $\begin{array}{l}\text { Law No. 9009, } \\
\text { dated } \\
\text { 13.02.2003 }\end{array}$ & $\begin{array}{l}\text { Internal audit is an independent activity which provides objective assurance and } \\
\text { directional guidance, designed to add value and to improve the public entity's actions. } \\
\text { It helps the subject through a systematic and disciplined approach to assess and to } \\
\text { improve the effectiveness of risk management, control and governance processes. }\end{array}$ \\
\hline $\begin{array}{l}\text { Law No. 9720, } \\
\text { dated } \\
23.04 .2007\end{array}$ & $\begin{array}{l}\text { Internal Audit is an independent activity that provides management and advice on the } \\
\text { management activity, the effective use of funds and the improvement of the activity } \\
\text { of audited entities, assisting them systematically and programmed to improve the } \\
\text { effective use of funds and to assessing the risk, performance, control and } \\
\text { management systems. }\end{array}$ \\
\hline $\begin{array}{l}\text { Law No. 10, } \\
\text { dated } \\
16.09 .2010\end{array}$ & $\begin{array}{l}\text { Internal Audit is an independent activity that provides objective assurance and } \\
\text { directional guidance, designed to increase value and improve the operations of the } \\
\text { public entity. It helps the public entity to achieve its objectives by means of a } \\
\text { disciplined and systematic way of assessing and improving the usefulness of risk } \\
\text { management, control processes and governance of the public entity. }\end{array}$ \\
\hline
\end{tabular}




\section{Journal of International Cooperation and Development \\ www.richtmann.org/journal \\ Vol 3, No 1, May 2020}

\begin{tabular}{|l|l|l|}
\hline $\begin{array}{l}\text { Law } \\
114 / 2015\end{array}$ & No. & $\begin{array}{l}\text { Internal Audit is an independent activity that provides objective assurance and } \\
\text { offering management advice designed to add value to improve the operation of the } \\
\text { public entity. Internal audit helps the public entity to achieve the objectives through a } \\
\text { disciplined and systematic activity to evaluate and improve the usefulness of risk } \\
\text { management as well as control and governance processes. }\end{array}$ \\
\hline
\end{tabular}

Source: Based on framework of internal audit in Albania

The external public audit function is covered by Albania's Supreme Audit Institution (ALSAI), or the High State Control. Currently, ALSAl activity' is regulated by Law No. 154/2014 "On the organization and functioning of state supreme audit institution". The purpose of ALSAI after the 1990s has modified from one period to another - Table 2:

Table 2: The purpose of ALSAI after the 1990s

\begin{tabular}{|c|c|}
\hline $\begin{array}{l}\text { Law No. } 7597, \\
\text { dated } 31.08 .1992\end{array}$ & $\begin{array}{l}\text { The State Audit Service, in accordance with the competencies defined by this law, } \\
\text { exercises control and performs an economic and financial audit at the Council of } \\
\text { Ministers, ministries and other central institutions, the Bank of Albania, state } \\
\text { second-tier banks, local government, budget institutions, state and joint ventures, } \\
\text { armed forces, political and social parties and organizations only for the funds } \\
\text { provided by the state budget. The State Control Service exercises control over the } \\
\text { apparatus of the People's Assembly and the President's Cabinet for the use of } \\
\text { material and financial funds. }\end{array}$ \\
\hline $\begin{array}{l}\text { Law No. } 8270, \\
\text { dated } 23.12 .1997 \\
\text { and Law No. } 8599, \\
\text { dated } \\
\text { 10. } 04.2000\end{array}$ & $\begin{array}{l}\text { The Supreme State Audit, in accordance with the legislation and international } \\
\text { standards of control elaborated by INTOSAI, controls the administration of state } \\
\text { property and the implementation of the state budget in the entities defined by } \\
\text { this law. The control covers issues of regularity, financial management and } \\
\text { evaluation. }\end{array}$ \\
\hline aw No. 154/2014 & $\begin{array}{l}\text { The State Supreme Audit Institution, through the audits, aims at the effective, } \\
\text { efficient and economical use of public funds, public and state property, the } \\
\text { development of an appropriate financial management system, the proper conduct } \\
\text { of administrative activities and the information of public authorities and public }\end{array}$ \\
\hline
\end{tabular}

Source: Based on framework of external public audit, The State Supreme Audit institution

The compliance with the acquis communautaire in the field of auditing is a necessary requirement in the steps of membership towards the European Union, as set out in Articles 70, 85 and 90 of the Stabilization and Association Agreement and Charper 32 of the acquis. The Law No. 154/2014 and Law No 114/2015 are not included in the assessment of the degree of approximation with the acquis communautaire. However, all laws and sub-legal acts on internal and external audit practice are in line with 


\section{Journal of International Cooperation and Development \\ www.richtmann.org/journal \\ Vol 3, No 1, May 2020}

international standards.

While analyzing the history of audit in Albania, we should also discuss legal improvements which have avoided overlapping audit structures and public financial inspection. The functions of these structures are regulated through a full legal framework and cooperation agreements. These structures play an important role in using public funds. The relationship between the internal auditors and external auditors is supported by the legal framework and the following rules:

1. Article 16 of Law No. 154/2014 represens the inter-institutional cooperation of the ALSAI with the Ministry of Finance and it has been concretized with a new Memorandum of Understanding to better coordinate and monitor the follow-up to audit recommendations in May 2017. The State Supreme Audit institution takes into account these findings, only if the standards used for these audits are in accordance with its own standards and the ones of international auditing.

2. Article 25 of Law No 114/2015 - The structures being responsible for harmonizing the internal auditing and the internal auditing units shall cooperate with the High State Audit based on the principles of continuous cooperation, commitment, understanding and mutual trust.

3. International standards for the professional practice of internal auditing, The Institute of Internal Auditors (IIA), Standard 2050 - Coordination and Reliance.

4. The International Standards of Supreme Audit Institutions, International Organization of Supreme Audit Institutions, INTOSAI GOV 9150 - Coordination and Cooperation between SAIs and Internal Auditors in the Public Sector.

\section{ALSAI Performance}

ALSAI has built up its institutional functioning in various dimensions through which the audit missions are intended to be improved by methodologically and technically enhancing the implementation of international auditing standards and the best practices of INTOSAI and EUROSAI, considering himself a servant of citizens and stakeholders, as well as a prime agent of the Assembly to guarantee a good governance. The auditing work aims to make the management of the public financial resources more effective, economical and efficient. In order to fulfill its mission, ALSAI's activity is based on the principles of integrity, independence, accountability, transparency, professionalism, public interest, co-operation, and objectivity.

Referring to Albania 2018 Report by the European Commission on 17.4.2018: "The focus of audit activities is on compliance audits determining economic damage and violations of rules, rather than on audits that could help prevent such damage in the first place. The focus on producing a large number of audit reports annually negatively impacts the quality of audit work and recommendations. Financial audits do not yet result in professional audit opinions." 


\section{Journal of International Cooperation and Development \\ www.richtmann.org/journal \\ Vol 3, No 1, May 2020}

\subsection{Types of audit}

In accordance with the legislation, ALSAI performs financial audits, compliance audits (legality and financial regularity), performance audits, information technology audits, as well as assesses overall functioning of the systems of internal control and audit bodies subject to audit, giving random opinions and recommendations. In Table 3 are presented the types of audits carried out and the total planned audits versus audits carried out during 2012-2018:

Table 3: The types of audits for the period 2012-2018

\begin{tabular}{|l|c|c|c|c|c|c|c|}
\hline Types of audit/Year & 2012 & 2013 & 2014 & 2015 & 2016 & 2017 & 2018 \\
\hline Compliance audits & 131 & 118 & 131 & 120 & 118 & 117 & 94 \\
\hline Financial Audits & 17 & 21 & 12 & 12 & 7 & 14 & 29 \\
\hline Thematic Audits & 6 & 8 & 9 & 12 & 14 & 5 & 24 \\
\hline Performance Audits' & 4 & 6 & 8 & 12 & 13 & 15 & 18 \\
\hline IT Audits & 0 & 0 & 0 & 2 & 2 & 5 & 6 \\
\hline Total fakt & 158 & 153 & 160 & 158 & 154 & 156 & 171 \\
\hline Total plan & 153 & 147 & 159 & 155 & 154 & 154 & 162 \\
\hline
\end{tabular}

Source: Based on the data of ALSAI Performance Reports 2012-2018.

As we can see from the table in 2018, there have been conducted 15 more audits than 2017 or otherwise said the year 2018 marks the largest number of audits carried out since 2012. ALSAI has focused its audit work in compliance audits, which represents the largest number of total audits. However, the number of such audits in 2018 has been reduced from 117 audits in 2017 to 94 audits in 2018. Over the years, the number of audits has been raised in some areas such as the IT audit, which was inexistent until in 2014 and the performance audit that raised from 4 in 2012 to 18 in 2018. It is also noted a significant increase in the number of financial audits compared to 2017, altogether 15 more audits. During this analyzed period, only in 2016 the ALSAI was in line with the target of planned audits at the beginning of the year, while in the other years we have exceeded the planned number of audits, and in 2018 were exceeded by 9 audits, the planned levels. The annual reports of ALSAI do not explain the factors that have led to deviations from the plan, indicating that better planning of audit resources is needed.

\subsection{The economic damage}

One way to measure the audit institutions performance is to analyze the level of damages and ineffective spending or spending with negative effects on the state budget. According to the published data of ALSAI Economic Damage 2002-2011 versus Economic Damage 2012-2018, the average of the economic damage discovered has grown with 


\section{Journal of International Cooperation and Development \\ www.richtmann.org/journal \\ Vol 3, No 1, May 2020}

$475 \%$ in the last years compared to the last 10 years, which demonstrates that the ALSAI have detected financial irregularities and economic damages. Its highest level was in year 2015 with 125.8 billion ALL and goes to 213.9 billion ALL or approximately 1,711.1 million euro in year 2018.

Table 4: Economic Damage Discovered 2002-2018

\begin{tabular}{|c|c|c|c|}
\hline & 10 years (2002-2011) & 7 years (2012-2018) & Percentage of growth \\
\hline $\begin{array}{c}\text { The economic damage } \\
\text { discovered (in billions ALL) }\end{array}$ & 47.7 & 226.7 & $475 \%$ \\
\hline
\end{tabular}

Source: Based on the data of ALSAI Performance Report 2018

For irregularities, financial violations with a negative impact on the performance of audited entities and lack of value added in the use of public funds, the ALSAI has lawsuit in the prosecution bodies, people responsible for a total of 307 criminal charges for the period 2012-2018. The highest number of criminal charges refers to 2015 (51 criminal charges) and has come down to 2018 (41 criminal charges) - Table 5.

Table 5: Criminal charges in years 2012-2018

\begin{tabular}{|l|c|c|c|c|c|c|c|}
\hline & 2012 & 2013 & 2014 & 2015 & 2016 & 2017 & 2018 \\
\hline Number of denunciations & 40 & 38 & 41 & 51 & 49 & 47 & 41 \\
\hline Number of People & 125 & 94 & 149 & 159 & 191 & 129 & 122 \\
\hline
\end{tabular}

Source: Based on the data of ALSAI Performance Report 2018

\section{Conclusions}

This paper traces the historical course of auditing in the public sector, which incurs changes decades after decade in order to meet the requirements of a business environment. In Albania, the modernization of the audit function has slowed down. The definitions, roles and types of audit have experienced their evolution theoretically, legally and practically, especially during the last century. After the fall of communism, many reforms which restructured the State Supreme Audit Institution were undertaken. Today the State Supreme Audit Institution is an independent and depoliticized institution, which exercises its powers subject to the Constitution, the legal framework in force and the international auditing standards. Now we can say that the experience and progress of the auditing show has made it an essential key to the advice of a strong and stable government, but further efforts are needed to give it the right importance and to fulfill its role. In order to further the modernization of this institution, the Law 


\section{Journal of International Cooperation and Development \\ www.richtmann.org/journal \\ Vol 3, No 1, May 2020}

No. $154 / 2014$, in which not only the term "control" has been replaced by the term "audit", but many changes have been made to the structure and content of the audit process.

One of the aspects that had a great impact on the development of auditing in the public sector was the approximation of the legislation with the International Standards of Supreme Audit Institutions developed by the INTOSAI in the field of external public auditing and with the IIA's International Standards in the field of internal audit. The implementation of these standards affects audit work to promote transparency and efficiency in public administration activities. The performance of performance audit and IT audit remain problematic, their number has increased from one year to the other, yet more investment is needed to increase the professional skills of auditors in carrying out these audits. It is important to mention the IT audit that was inexistent in 2012, now is part of the work of ALSAI.

Nowadays the audit should be considered as a management tool that adds value and improves the activity of the public sector. External and internal auditing should cooperate and co-ordinate their work with public institutions auditing, aiming for quality work of audit effort and implementation of recommendations as an instrument to combat misuse and mismanagement of public funds. In order to minimize the risks in the future, we suggest an amplification of the audit function in Albania, focusing on strengthening legal bases, increasing transparency to the public, liability and accountability of the head of entities for better use of the public financial goods.

\section{References}

Angjeli G., (2014), Auditimi dhe qeverisja e mire, Monografi, UMSH Press - KLSH, Classic Print, Tirane, ISBN: 978-9928-4246-0-0.

Avram, M. (2013). The role of the annual financial statements in the management of the company. Annals of the "Constantin Brâncuşi" University of Târgu Jiu, Economy Series, Issue 1/2013, p. 13-18, ISSN $1844-7007$.

Avram, C. D. (2017). Some Considerations on The Role of Financial Communication Within Corporate Governance. "Ovidius" University Annals, Economic Sciences Series, Volume XVII, Issue 1 /2017, p: 398-402, ISSN: 1582-9383.

Brown, R. (1905). A history of accounting and accountants. Cosimo Classics, New York, October 01, 2006, (originally published by Augustus M. Kelley Publishers, in 1905), p. 74, ISBN: 159605-961-3.

Cibaku, Q. (2010). Projeksione teorike mbi kontrollin dhe auditimin. Epoka University Publications, p.98, ISBN: 978-99956-681-8-1. Retrieved from https://vdocuments.site/dispense-mbiteorine-e-auditimit.html

Çela, H. (2017). Auditimi i pasqyrave financiare. Publisher: albPAPER, p.10, ISBN: 978-9928-05238-4.

Flint, D. (1988). Philosophy and principles of auditing: an introduction. Macmillan Press Ltd, p.xii, ISBN $100333311159,0333311167$. 


\section{Journal of International Cooperation and Development}

www.richtmann.org/journal

Vol 3, No 1, May 2020

Hay, D. \& Cordery, C. J. (2016). The Value of Public Sector Audit: Literature and History. p.33, Available at http://dx.doi.org/10.2139/ssrn.2895809

Matthews, D. (2006). A History of Auditing: The Changing Audit Process in Britain from the Nineteenth Century to the Present Day, Routledge, 1st Edition (March 6, 2006), p. 2, ISBN: 0-415-38169-X.

Mautz, R. K., \& Sharaf, H. A. (1961). The philosophy of auditing. Sarasota, Fla: American Accounting Association, p. 186, ISBN: 0865390029.

Naska K., et al. (2012). Historiku i Kontrollit të Lartë të Shtetit 1925-2012, Seria: Botimet KLSH 09/2012, ISBN: 978-9928-159-06-9. Retrieved from: http://www.klsh.org.al/web /historiku_klsh_838.pdf

Ramamoorti, S. (2003). Chapter 1. Internal Auditing: History, Evolution, and Prospect, Journal Research opportunities in internal auditing, The Institute of Internal Auditors Research Foundation, pp. 1-23, ISBN 0-89413-498-1.

Albania 2018 Report from the European Commission. Retrieved from https://ec.europa.eu /neighbourhood-enlargement/sites/near/files/20180417-albania-report.pdf

Albania Public Finance Management Strategy 2014- 2020. Retrieved from https://www.financa .gov.al/wp-content/uploads/2017/09/Albanian_PFM_strategy_2014-2020-1.pdf

ALSAI Performance Report 2016. Retrieved from: http://www.klsh.org.al/web/alsai _performanca_compressed_3249.pdf

ALSAI Performance Report 2018. Retrieved from: http://www.klsh.org.al/web/raporti _performances_2018_4788.pdf

ALSAI Performance Report 2017. Retrieved from: http://www.klsh.org.al/web/raporti_i performances_4085.pdf

ALSAI Performance Report 2015. Retrieved from: http://www.klsh.org.al/web/raporti_i _performances_se_klsh_2015_2624.pdf

ALSAI Performance Report 2014. Retrieved from: http://www.klsh.org.al/web /performaca_2014_2260_1_1_3233.pdf

ALSAI Performance Report 2013. Retrieved from: http://www.klsh.org.al/web/raporti _performances_se_klsh_2013_1159.pdf

ALSAI Performance Report 2012. Retrieved from: http://www.klsh.org.al/web/performanca _klsh_2012_652.pdf

Chapters of the acquis. Retrieved from: https://ec.europa.eu/neighbourhoodenlargement/policy/conditions-membership/chapters-of-the-acquis_en

Framework of intenal audit. Retrieved from https://www.financa.gov.al/en/; https://financa.gov.al/;

Framewok of internal and external public audit, https://qbz.gov.al/Botime/Akteindividuale /Janar\%202018/Fletore\%2069/VKM\%20nr.\%20246,\%20date\%209.5.2018.pdfhttps:

Framework of external public audit, The State Supreme Audit institution. Retrieved from: http://www.klsh.org.al/web/THE_SUPREME_STATE_AUDIT_1_2.php

Law No 114/2015, on Internal Auditing in the Public Sector, published in: the Official Journal no. 195 of November 13, 2015.

Law No. 154/2014 "Organization and Functioning of State Supreme Audit Institution"

The Institute of Internal Auditors (IIA), Standard 2050 - Coordination and Reliance, https://na.theiia.org/standards-guidance/Public\%20Documents/IPPF-Standards-2017.pdf 


\section{Journal of International Cooperation and Development}

www.richtmann.org/journal

Vol 3, No 1, May 2020

INTOSAI GOV 9150, http://www.issai.org/issai-framework/intosai-gov.htm

Stabilisation and Association Agreement between the European Communities and their Member States, of the one part, and the Republic of Albania, of the other part, (2009) Retrieved from: https://eur-lex.europa.eu/LexUriServ/LexUriServ.do?uri=OJ:L:2009 :107:0166:0502:en:PDF 